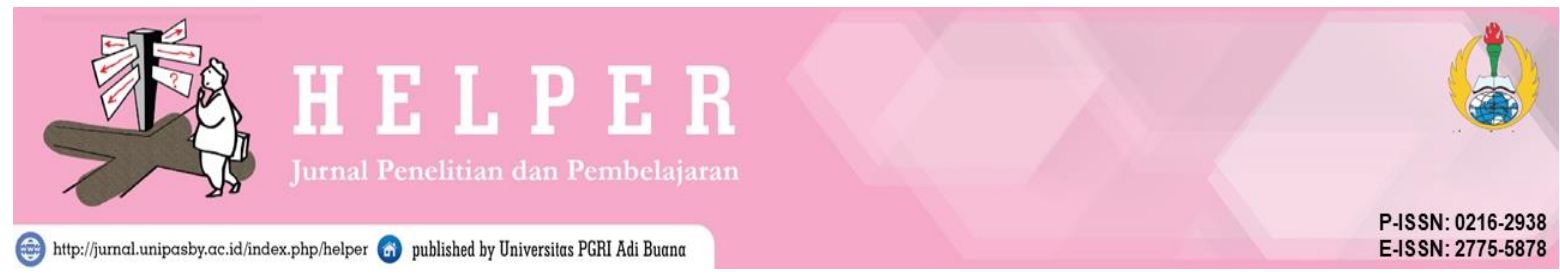

Vol. 38 No. 1 (2021)

\title{
SURVEY PELAKSANAAN LAYANAN BIMBINGAN KARIER DI SMP NEGERI 3 WARU
}

\author{
Siti Nur Khoiriyah \\ ${ }^{1}$ Bimbingan dan Konseling, Universitas Adi Buana Surabaya, Surabaya, Indonesia \\ *Email: riariaa20@gmail.com \\ Aniek Wirastania \\ ${ }^{1}$ Bimbingan dan Konseling, Universitas Adi Buana Surabaya, Surabaya, Indonesia \\ *Email: aniek@unipasby.ac.id
}

\begin{abstract}
Abstrak
Layanan bimbingan karier akan berpengaruh pada pemahaman karier siswa, rendahnya pemahaman karier akan berdampak pula dengan masa depan seseorang. Tujuan penelitian ini adalah untuk mengetahui bagaimana pelaksanaan layanan bimbingan karier di SMP Negeri 3 Waru. Metode yang digunakan dalam penelitian ini yakni dengan pendekatan deskriptif kualitatif . Objek penelitian ini adalah guru BK dan siswa kelas 9 dengan sampel 2 guru BK dan 2 siswa. Penelitian ini menggunakan 3 metode yaitu observasi, wawancara dan dokumentasi.Hasil penelitian yang ditemukan yaitu pelaksanaan layanan bimbingan karier di SMP Negeri 3 Waru berjalan dengan baik,guru Bk memberikan layanan bimbingan karier dengan maksimal sehingga siswa dapat memahami diri, dapat merencanakan kariernya di masa depan dan memiliki pemahaman karier yang baik untuk dapat menentukan langkah-langkah kongkret untuk mencapai cita-cita maupun karier di masa depan.
\end{abstract}

Kata Kunci: Layanan Bimbingan Karier, Pemahaman Karier siswa

\begin{abstract}
Abstact
Career guidance services will effect student's career understanding, low career understanding will also have an impact on a person's future. The purpose of this study was to determine how the implementation of career guidance services at SMP Negeri 3 Waru. The method used in this research is a qualitative descriptive approach. The object of this research is the counseling teacher and students of grade 9 with a sampleof 2 counseling teachers and 2 students. This study uses 3 methods namely observation, interviews, and documentation. The results found were the implementation of career guidance services at SMP Negeri 3 Waru running well the guidance and counseling teachers provide maximum career guidance services so that students can understand themselves, can plan their future careers, and have a good career understanding to be able to determine concrete steps to achieve goals and careers in the future
\end{abstract}

Keywords: Career Guidance Service, Career Students Understanding 


\section{PENDAHULUAN}

Karier sering kali diartikan sebagai pekerjaan dan jabatan, karier merupakan perkembangan dan kemajuan dalam pekerjaan seseorang. Menurut (Hartono, 2016) karier adalah aktivitas profesioal berkaitan dengan pekerjaan seseorang. Karier merupakan sebuah gambaran kemajuan seseorang dalam pekerjaannya dan kemajuan itu diwujudkan dengan pencapaian prestasi kerja, karier berguna untuk keberlangsungan hidup seorang individu, dengan berkarier seorang individu dapat memenuhi kebutuhanya,selain itu karier juga dapat meningkatkan status sosial seorang individu. Pendidikan adalah salah satu tahapan seorang individu agar dapat berkarier.

Pendidikan yang bermutu dapat mengembangkan potensi individu juga dapat memecahkan problematika kehidupan individu. Peran penting pendidikan adalah untuk mempersiapkan siswa sebagai individu yang kelak dapat bersaing juga sebagai pemegang kunci kesuksesan. Pemahaman karier yang baik diharapkan dapat membantu siswa dalam menentukan pilihan kariernya di masa depan dan kemudian dapat menentukan langkah kongkret untuk mencapai karier yang dipilihnya.

Permasalahan tentang kesulitan menentukan karier selain dapat memperbesar persentase pengangguran juga akan memicu problematika lainnya seperti meningkatnya kriminalitas, meningkatkan angka kemiskinan karena tidak bekerja maka tidak dapat memenuhi kebutuhan hidup, dan masalah psikologis dan mental individu, terhambatnya pertumbuhan ekonomi negara juga masalah sosial lainnya. Problematika ini yang menjadi alasan mengapa karier dianggap hal yang penting bagi individu oleh karena itu diperlukan upaya untuk mengatasinya agar nantinya individu itu dapat mempersiapkan diri dan mampu bersaing dalam berkarier sehingga diharapkan dapat meminimalisir problematika yang akan ditimbulkan jika kesulitan dalam menentukan karier karena tidak memahami potensi diri.

Menurut (Rohmah dan Falah, 2016) Bimbingan dan konseling adalah sebuah rangkaian layanan bantuan yang diberikan oleh guru Bk kepada siswa untuk membantu mengatasi masalah dan gar siswa dapat berkembang menjadi lebih baik. Bimbingan konseling di sekolah memiliki peran penting dalam karier siswa, bimbingan konseling memiliki layanan-layanan salah satunya yakni layanan bimbingan karier. Layanan bimbingan karir yaitu layanan yang diberikan untuk membantu individu dalam merencanakan, mengembangkan, dan menyelesaikan masalah-masalah karier, seperti pemahaman terhadap dunia kerja, pemahaman kompetensi dalam diri, kemudian merencanakan dan pengembangan karir, penyesuaian pekerjaan yang dipilih (Prayoga, Asrori dan Wicaksono, 2018).

Bimbingan karier adalah suatu cara untuk menumbuhkan keinginan seseorang untuk memiliki karier yang akan dipilih sendiri. Bimbingan karier adalah layanan pembelajaran yang mengacu pada pemahaman karier di masa depan (Widarto , 2015). Layanan bimbingan karier adalah layanan yang di berikan oleh guru BK kepada siswa yang berisikan informasi mengenai karier. 
Bimbingan karier adalah layanan yang diberikan untuk merencanakan dan mengembangkan masa depan berkaitan dengan dunia pendidikan maupun dunia karier.

Teori bimbingan karier menurut Super (Fitriyani, Handayani, putri, dkk, 2019) adalah teori yang meyakini pilihan karier sebagai bentuk perkembangan. Teori ini dasarnya adalah kerja itu merupakan wujud konsep diri. Setiap orang memiliki konsep diri dan dia berusaha menerapkan konsep diri itu dengan memilih pekerjaan. Menurut teori Super, memilih karier adalah soal mencocokkan antara konsep diri dan karier di masa depan, Proses kehidupan seseorang mempengaruhi perwujudan konsep diri dalam pemilihan karir karena akan terjadi perubahanperubahan pada individu dan situasi lingkungannya. Pemilihan karir adalah tahap perkembangan orang dan prosesnya berlangsung dalam rangka penunaian tugas-tugas perkembangan. Tugas-tugas perkembangan itu adalah memilih karir yang disukai (14-18 tahun), spesifikasi karier yang di pilih (18-21 tahun), implementasi pilihan karir (21-25 tahun), stabilisasi di dalam suatu pekerjaan (25 - 35 tahun), dan konsolidasi status dan kemajuan (masa akhir usia 30-an dan pertengahan usia 40-an).

Pelaksanaan layanan bimbingan karier di sekolah seharusnya dapat diberikan secara maksimal agar siswa memiliki pemahaman tentang karier dengan baik. Berdasarkan hasil studi pendahuluan (Kushendar, 2019) di SMP Negeri 1 Palembang, mengidentifikasi adanya gejala kebingungan seperti siswa yang masih bingung untuk menentukan atau memilih sekolah lanjutan, hal tersebut diketahui oleh peneliti karena kurangnya informasi mengenai sekolah lanjutan bagi siswa Sekolah Menengah Pertama (SMP) untuk melanjutkan ke mana ke SMA, MA, atau SMK dan juga peneliti mengidentifikasi adanya perbedaan pendapat dengan orangtua mereka yang sebenarnya permasalahan itu dikarenakan karena kurangnya informasi serta tidak memahami prosfek dari karir yang akan dipilih yang mengakibatkan ketidaksesuaian keinginan orangtua dengan keinginan peserta didik itu sendiri sehingga peserta didik bingung dan belum punya kepastian akan keputusannya dalam memilih dan menentukan sekolah lanjutan, maka dari itu siswa perlu dibantu dengan pemahaman dari Guru BK

Layanan bimbingan karier hendaknya diberikan sesuai kebutuhan siswa, selain itu pemberian layanan juga dilihat dari tingkatan sekolah. SMP Negeri 3 Waru adalah sekolah yang memberikan layanan bimbingan dan konseling, salah satunya adalah layanan bimbingan karier. Peneliti melakukan penelitian untuk mengetahui bagaimana pelaksanaan layanan bimbingan karier di SMP Negeri 3 Waru dengan melakukan observasi langsung ke sekolah guna mengetahui ada atau tidaknya kendala maupun hambatan dalam pelaksanaan layanan bimbingan karier di SMP Negeri 3 Waru yang diberikan guru BK kepada siswa. Saat ini sedang terjadi pendemi Covid-19 yang memaksa kegiatan belajar mengajar tidak bisa dilaksanakan secara tetap muka sehingga pemberian layanan BK juga dilakuka secara daring, penelitian ini juga untuk mengetahui apakah ada perbedaan dalam pelaksanaan layanan bimbingan karier sebelum dan saat pademi Covid-19. 


\section{METODE}

Penelitian ini menggunakan pendekatan kualitatif. Metode penelitian yang digunakan dalam penelitian ini adalah metode deskriptif kualitatif yang bertujuan menggambarkan dan memahami tentang pelaksanaan layanan bimbingan karier di Sekolah Menengah Pertama Negeri 3 Waru yang diteliti dalam bentuk kata-kata dan bahasa, pada suatu konteks khusus yang alamiah dengan memanfaatkan berbagai metode penelitian. sumber data utama dari kata-kata dan tindakan orangorang yang berkaitan yakni guru BK dan siswa kelas 9 pelaksanaan layanan Bimbingan Karir kelas IX di SMP Negeri 3 Waru dalam bentuk wawancara mengenai perencanaan, pelaksanaan, dan tindak lanjut layanan Bimbingan Karir. Metode pengumpulan data yakni dengan observasi, wawancara, dan dokumentasi. Teknik analisis data yakni menggunakan triangulasi data yaitu dengan menggambarkan hasil penelitian dengan kata-kata atau deskriptif. Analisis data dengan Triangulasi yaitu memadukan hasil observasi,wawancara serta studi dokumentasi yang telah didapatkan selama pelaksanaan penelitian.

\section{HASIL DAN PEMBAHASAN}

Pelaksanaan layanan bimbingan karier di SMP Negeri 3 Waru diberikan kepada siswa kelas 9 saja karena siswa kelas 7 dan 8 diberikan layanan mengarah kepada peminatan, pelaksanaan layanan telah dilaksanakan dengan baik. peneliti menemukan terdapat perbedaan dalam pelaksanaan layanan bimbingan karier sebelum dan saat pandemi Covid-19 yakni saat sebelum pandemi pelaksanaan layanan bimbingan karier diberikan secara tatap muka di dalam kelas, dan saat pandemi pelaksanaan layanan bimbingan karier di SMP Negeri 3 Waru diberikan secara daring.

Hasil observasi yang dilakukan oleh peneliti di SMP Negeri 3 Waru tentang pelaksanaan layanan bimbigan karier yakni guru BK memberikan layananan bimbingan karier yang optimal untuk siswa. Guru BK memberikan layanan bimbingan karier dengan menggunakan media seperti pohon karier dan majalah dinding sekolah. Guru BK juga memiliki catatan administratif tentang minat sekolah lanjutan siswa dan sekolah lanjutan yang akhirnya dipilih siswa.

Pelaksanaan layanan bimbingan karier sebelum dan saat pandemi menurut hasil wawancara dengan guru BK yakni layanan bimbingan karier sebelum pandemi memiliki perbedaan. Layanan bimbingan karier sebelum pandemi diberikan secara tatap buka di dalam kelas menggunakan modul bimbingan karier untuk penyampaian materi selain itu guru BK mengajak siswa bermain peran memerankan profesi dalam karier seperti dokter, guru dan polisi. Guru BK juga memaksimalkan layanan bimbingan karier dengan mendatangkan alumni guna memberi gambaran langsung kepada siswa tentang sekolah lanjutan seperti jurusan-jurusan yang ada di sekolah lanjutan sehingga siswa mendapatkan informasi tentang karier lebih luas. 
Pelaksanaan layanan bimbigan karier saat pandemi berbeda dengan pelaksanaan layanan bimbingan karier seblum pandemi, Pelaksanaan layanan bimbingan karier saat pandemi hanya dapat dilaksanakan secara daring. Pelaksaaan layanan bimbingan karier secara daring ini menggunakan aplikasi Whatsapp, guru BK mengirimkan materi tentang karier berupa PPT maupun video dalam whatsapp grub yang kemudian dibaca dan dipahami oleh siswa. Layanan bimbingan karier saat pendemi ini dimaksimalkan dengan pemberian layanan konsultasi pribadi apabila ada siswa yang masih mengalami kesulitan tentang pemahaman karier.

Hasil dokumentasi media yang digunakan guru BK untuk memberikan layanan bimbingan karier dan materi yang diberikan guru BK dalam memberikan layanan bimbingan karier kepada siswa.

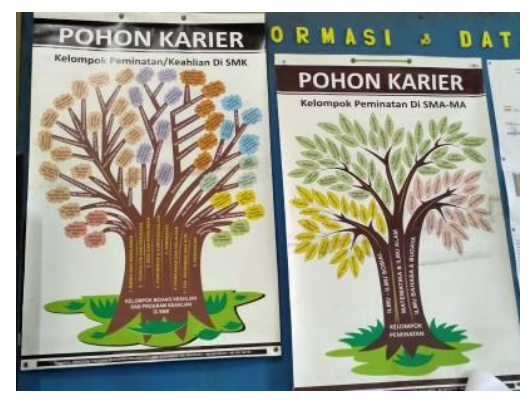

Gambar 1. Media BK, gambar pohon karier
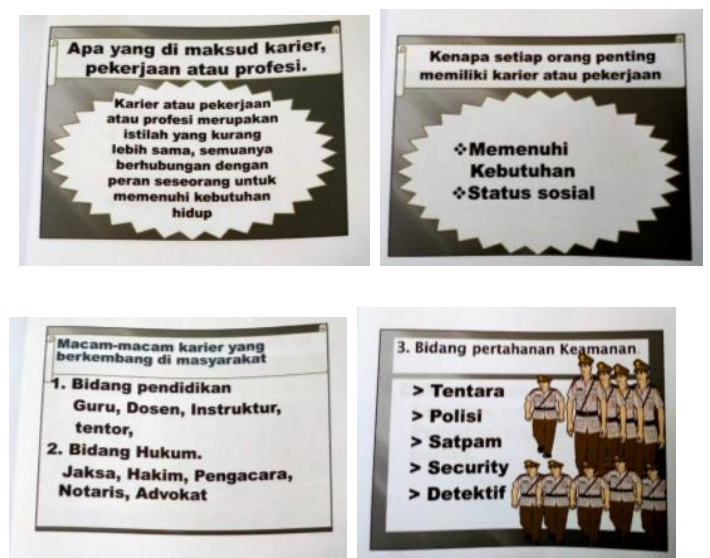

Gambar 1.1 Materi layanan bimbingan karier

Media dan materi tersebut diatas digunakan guru BK dalam memberikan layaan bimbingan karier kepada siswa. materi dan media yang digunakan berisi tentang karier yakni profesi-profesi di berbagai bidang. Layanan bimbingan karier diberikan dengan materi dan didukung media agar siswa dapat lebih mudah untuk memahami tentang karier.

Layanan bimbingan karir adalah suatu upaya berupa pemberian bantuan yang oleh konselor ataupun guru BK kepada siswa agar dapat memahami diri dan potensinya, mengenal dan memahami dunia kerja, serta merencanakan masa depan yang sesuai dengan apa yang diharapkan ataupun citacitanya. Layanan bimbingan karier dirasa sangat penting agar dapat digunakan sebagai acuan agar siswa tidak sampai salah dalam pemilihan karier karena tidak dapat memahami potensi,minat dan 
bakat yang dimiliki sehingga kurang maksimal dalam mencapai cita-cita di masa depan (Widiyanti dan Makin, 2019). Pemahaman yang dimiliki siswa di SMP Negeri 3 Waru tentang karier dinilai sangat baik, siswa dapat memahami kemampuan diri,minat,bakat dan potensi diri sehingga dapat memilih karier yang sesuai dengan kemampuan yang dimiliki, selain itu siswa juga dapat menentukan atau mrencanakan langkah-langkah kongkrit untuk mencapai cita-cita ataupun karier yang dipilihnya.

Pemberian layanan bimbingan karier memiliki tujuan agar siswa dapat memahami, memilih dan merencanakan karir apa yang diinginkannya setelah tamat dari pendidikan dan dapat mengenal dunia kerja yang sesuai dengan dirinya. Tujuan pemberian layanan bimbingan karier adalah untuk membantu siswa memperoleh kompetensi yang diperlukan agar dapat mengembangkan karier yang dipilihnya secara maksimal dan memberikan gambaran tentang persyaratan suatu jabatan tertentu sehingga siswa dapat memahami diri, mampu menentukan arah pemilihan karier dan pada akhirnya membantu siswa dalam merencanakan masa depannya (Prayoga, Asrori, dan Wicaksono, 2018). Pelaksanaan layanan mbingan karier di SMP Negeri 3 Waru telah mencapai tujuan layanan bmbingan karier, hal ini dibuktikan dengan pemahaman karier yang dimiliki siswa kelas 9 di SMP Negeri 3 Waru

\section{KESIMPULAN}

Pelaksanaan layanan bimbingan karir diberikan kepada siswa kelas 9 yang dilaksanakan oleh guru BK. Pemberian layanan bimbingan karier memiliki perbedaan saat sebelum pandemi Covid-19 dan saat pandemi Covid-19 yaitu sebelum pandemi Covid-19 layanan bimbingan karier dilaksanakan dengan Bimbingan klasikal secara tatap muka juga bermain peran, selain itu juga siswa mendapat gambaran langsung dari alumni tentang sekolah lanjutan. Saat pandemi Covid-19 layanan bimbingan karier diberikan secara daring menggunakan aplikasi whatsapp, materi diberikan dalam whatsapp grub yang kemudian dibaca dan dipahami oleh siswa, jika masih ada siswa yang belum paham tentang informasi karier guru BK akan memberikan konsultasi pribadi.

Pelayanan bimbingan karier di SMP Negeri 3 Waru telah berjalan dengan baik hal ini dibuktikan oleh pemahaman tentang karier yang dimiliki siswa dan perencanaan karier untuk masa depan yang sangat baik. Hal ini tentu tidak lepas dari pelaksanaan layanan bimbingan karier yang diberikan oleh guru BK dengan semaksimal mungkin yakni membimbing, mengarahkan dan memberikan informasi demi mencapai tujuan layanan bimbingan karier dengan memanfaatkan sarana dan prasarana yang ada di sekolah untuk menunjang pelaksanaan layanan bimbingan karier sehingga siswa mencapai pemahaman karier dan dapat menentukan pilihan kariernya di masa depan.

Guru BK dalam melaksanakan layanan bimbingan karir hendaknya memperluas dan memperdalam informasi tentang karier sehingga lebih banyak informasi yang dapat di berikan kepada siswa, dan Menyiapkan materi yang mudah dipahami oleh siswa. selain itu sekolah juga diharapkan Menyediakan Ruang BK yang lebih memadai dan memenuhi standart agar pelayanan BK dapat 
dilaksanakan dengan semaksimal mungkin. Kontribusi pada ilmu bimbingan konseling dalam pelaksanaan bimbingan karier selanjutnya diharapkan mampu meningkatkan kualitas bimbingan dan konseling di sekolah

\section{UCAPAN TERIMA KASIH}

Terima kasih saya ucapkan para narasumber yang bersedia membantu saya dalam melakukan penelitian.

\section{DAFTAR PUSTAKA}

Fitriyani Nina, Handayani Riska, Putri Dwinda Tiara Putri, Hidayat Dede Rahmat. 2019. Implementasi Teori Donald E. Super Pada Program Pelayanan Bimbingan Karir Untuk Siswa Sekolah Menengah Pertama, Jurnal Ilmu dan Budaya, Vol .41, No. 65

Hartono. 2016. Bimbingan Karier. Surabaya: Penerbit Prenadamedia Group.

Kushendar. 2019. Strategi Bimbingan Karir Menggunakan Layanan Klasikal Untuk Meningkatkan Pemahaman Perencanaan Pemilihan Sekolah Lanjutan Siswa SMP : Experimental Design, Jurnal Bimbingan Konseling Vol. 5, No.1

Prayoga Yanda, Asrori Mohammad, Wicaksono Luhur. 2018. Analisis Pelaksanaan Bimbingan Karir Pada Peserta Didik Kelas IX SMP Negeri 12 Pontianak, Jurnal Pendidikan dan Pembelajaran Vol 7, No 4 Rohmah Khanifatur, Falah Nailul. 2016. Layanan Bimbingan Karir Untuk Meningkatkan Motivasi Melanjutkan Pendidikan Ke Perguruan Tinggi Pada Siswa SMA Negeri 1 Depok Sleman D.I Yogyakarta, Jurnal Hisbah, vol. 13, No.1.

Widarto. 2015. Bimbingan Karier dan Tips Berkarier. Yogyakarta: Penerbit Leutika Prio.

Widiyanti Trihana, Makin. 2019. Layanan Bimbingan Karir Dalam Upaya Meningkatkan Kemampuan Perencanaan Karir Pada Siswa Kelas XII SMK Kesehatan Insan Mulia Yogyakarta Tahun Ajaran 2018/2019. G-COUNS: Jurnal Bimbingan dan Konseling Vol. 3 No. 2. 